\title{
The durability of normal strength concrete: an experimental study
}

\author{
V. Patel \& N. Shah \\ Civil Engineering Department, \\ Charotar University of Science and Technology, India
}

\begin{abstract}
The present study is carried out for evaluating the effect of aggressive environments like sulphate and chloride exposure on normal strength concrete. This paper presents results of experiments like the compression test $(150 \mathrm{~mm} \times 150 \mathrm{~mm} \times 150 \mathrm{~mm}$ size cubes $)$, rebound hammer test and ultrasonic pulse velocity test $(150 \mathrm{~mm} \times 150 \mathrm{~mm} \times 150 \mathrm{~mm}$ size cubes $)$, split tensile test $(100 \mathrm{~mm}$ diameter $\times 200 \mathrm{~mm}$ height cylinders), rapid chloride penetration test (100mm diameter, $50 \mathrm{~mm}$ thickness specimen), sulphate and chloride attack test $\left(150 \mathrm{~mm} \times 150 \mathrm{~mm} \times 150 \mathrm{~mm}\right.$ size cubes) performed on $\mathrm{M}_{30}$ grade concrete. The results clearly indicated that normal strength concrete cannot contribute significantly against sulphate and chloride attack.

Keywords: normal strength concrete, aggressive environment, sulphate and chloride attack, rapid chloride penetration.
\end{abstract}

\section{Introduction}

Normal strength concrete is a widely used construction material with a compressive strength of $20 \mathrm{MPa}$ to $40 \mathrm{MPa}$. The durability of normal strength concrete is very important for a particular application and environment to which it will be exposed. Premature deterioration of concrete long before its service life has become a critical issue [1]. Much research has been done to increase the strength of concrete by adding different admixtures and checking the behaviour of concrete under different environments like industrial effluents [2]. Permeability depends upon on the extent of hydration of cementitious material. The curing condition and age of concrete largely determines the ease with which chloride ions can move into a concrete [3]. Concrete deterioration occurs when 
it is exposed to weather, water or chemicals over a long period of time. The durability of concrete is of vital importance regarding the life cycle cost of a structure [4]. The life cycle cost includes initial cost of materials and labour and cost of maintenance and repair. The selection of proper materials and good quality control are essential for durability of concrete. The chloride dissolved in water increase the rate of leaching and thus increases the porosity of concrete and strength and stiffness decreases. Sodium and magnesium sulphates are in increasing order harmful to concrete as they react with hydrated cement paste which decreases the strength [5]. When RCC structures are exposed to harsh environments, deterioration of concrete occurs due to chloride and sulphate attack. Therefore, the degree of exposure of the environment condition to which concrete is subjected over its entire life is also very important [6]. This research was performed to generate data on durability characteristic of normal strength concrete so later on value added high performance concrete can be developed which can overcome all durability related deficiencies of normal strength concrete.

\section{Experimental study}

\subsection{Materials used}

\subsubsection{Cement}

Ordinary Portland cement Sanghi-53 grade confirming IS 12269: 1987 [7] was used in the present study with properties listed in Table 1.

Table 1: Properties of OPC 53 grade Sanghi cement.

\begin{tabular}{|c|c|c|}
\hline Sr. No. & Properties & Results \\
\hline 1 & Loss of ignition & 1.56 \\
\hline 2 & $\% \mathrm{SiO}_{2}$ & 19.70 \\
\hline 3 & $\% \mathrm{CaO}$ & 63.44 \\
\hline 4 & Specific gravity & 3.15 \\
\hline 5 & $\%$ Normal consistency & 29.5 \\
\hline 6 & Specific surface $\left(\mathrm{m}^{2} / \mathrm{kg}\right)$ & 306 \\
\hline 7 & Initial setting time (minutes) & 145 \\
\hline 8 & Final setting time (minutes) & 185 \\
\hline \multirow[t]{3}{*}{9} & Compressive strength (MPa) 3days & 37.5 \\
\hline & 7days & 48.5 \\
\hline & 28days & 63.0 \\
\hline
\end{tabular}




\subsubsection{Coarse aggregate}

Crushed angular aggregates confirming IS 383: 1970 [8] with maximum size of $20 \mathrm{~mm}$ was used having a bulk density of $1600 \mathrm{~kg} / \mathrm{m}^{3}$. The specific gravity was found to be 2.81 .

\subsubsection{Fine aggregate}

River sand from local sources confirming IS 383: 1970 [8] was used as fine aggregate. The fineness modulus, specific gravity and water absorption were found to be $2.64,2.82$ and $1.87 \%$ respectively.

\subsubsection{Water}

Fresh potable water free from acid and organic substances was used for mixing and curing the concrete.

\subsection{Mix proportion}

The mix proportion shown in Table 2 was made for a concrete with slump 30$50 \mathrm{~mm}$ and $\mathrm{M}_{30}$ grade as per mix design method specified by ACI committee 211.1-91 [14].

Table 2: $\quad$ Mix proportion of $\mathrm{M}_{30}$ grade concrete.

\begin{tabular}{|c|c|c|c|c|}
\hline $\begin{array}{c}\text { W/C } \\
\text { ratio }\end{array}$ & Cement $(\mathrm{kg})$ & Fine aggregate $(\mathrm{kg})$ & Coarse aggregate $(\mathrm{kg})$ & Water (liter) \\
\hline 0.45 & 411 & 880 & 992 & 185 \\
\hline
\end{tabular}

\subsection{Casting and curing}

Mixing of ingredients was done according to specifications given in IS 516: 1959 [9] by machine mixing. The concrete was filled into the moulds in layers approximately $5 \mathrm{~cm}$ deep and compacted by vibrator. The specimens were removed from the moulds after 24 hours and were kept submerged in curing tank. After curing for a period of 7 and 28 days, specimens were taken out and dried before testing.

\subsection{Testing}

Specimens were tested to ascertain properties at 7 and 28 days by performing the following tests.

\subsubsection{Compression test}

A compression test on cubes of size $150 \mathrm{~mm} \times 150 \mathrm{~mm} \times 150 \mathrm{~mm}$ was conducted on the compression testing machine (Aimil, $2000 \mathrm{kN}$ capacity). The load on cube was applied at a rate $5.2 \mathrm{kN} / \mathrm{s}$ up to the failure of specimen. The average compressive strength of three cubes was taken after 7 and 28 days curing. 
Table 3: Compression test results on cubes.

\begin{tabular}{|c|c|c|c|c|c|c|c|}
\hline $\begin{array}{c}\text { Date of } \\
\text { casting }\end{array}$ & \multicolumn{2}{|c|}{ Dimensions (mm) } & \multicolumn{2}{c|}{ Test results at 7 days } & \multicolumn{2}{c|}{ Test results at 28 days } \\
\cline { 2 - 8 } & Length & Width & $\begin{array}{c}\text { Thick- } \\
\text {-ness }\end{array}$ & $\begin{array}{c}\text { Failure } \\
\text { load } \\
(\mathrm{kN})\end{array}$ & $\begin{array}{c}\text { Compressive } \\
\text { stress } \\
(\mathrm{Mpa})\end{array}$ & $\begin{array}{c}\text { Failure } \\
\text { load } \\
(\mathrm{kN})\end{array}$ & $\begin{array}{c}\text { Compressive } \\
\text { stress } \\
(\mathrm{Mpa})\end{array}$ \\
\hline $25 / 01 / 13$ & 150 & 150 & 150 & 514.6 & 22.87 & 943 & 41.91 \\
\hline
\end{tabular}

\subsubsection{Rebound hammer test}

The rebound hammer test was performed on cubes of size $150 \mathrm{~mm} \times$ $150 \mathrm{~mm} \times 150 \mathrm{~mm}$ by pressing a plunger of a rebound hammer against the surface of concrete vertically downward as specified in IS 13311 (part 2): 1992 [10]. The rebound was read off along a graduated scale and was designated as the rebound number.

Table 4: Rebound hammer test results.

\begin{tabular}{|c|c|c|c|c|c|c|c|}
\hline \multirow{2}{*}{$\begin{array}{c}\text { Date of } \\
\text { casting }\end{array}$} & \multicolumn{2}{|c|}{ Dimensions (mm) } & \multicolumn{2}{c|}{ Test results at 7 days } & \multicolumn{2}{c|}{ Test results at 28 days } \\
\cline { 2 - 8 } & Length & Width & $\begin{array}{c}\text { Thick- } \\
\text {-ness }\end{array}$ & $\begin{array}{c}\text { Rebound } \\
\text { number }\end{array}$ & $\begin{array}{c}\text { Compressive } \\
\text { strength (MPa) }\end{array}$ & $\begin{array}{c}\text { Rebound } \\
\text { number }\end{array}$ & $\begin{array}{c}\text { Compressive } \\
\text { strength (MPa) }\end{array}$ \\
\hline $25 / 01 / 13$ & 150 & 150 & 150 & 22.33 & 18.4 & 31.66 & 33.66 \\
\hline
\end{tabular}

\subsubsection{Ultrasonic pulse velocity test}

Mix proportion used in making, compacting and curing of concrete is very important as they affect the density and modulus of elasticity of concrete. The ultrasonic pulse velocity of concrete is related to these. Concrete quality was checked as per specifications given in IS 13311 (part 1): 1992 [11]. The ultrasonic pulse was produced by transducer which was held in contact with one surface of the concrete member. After travelling a known path length in the concrete, the pulse of vibration was converted into an electrical signal by the second transducer held in contact with the other surface of the concrete member and the transit time of the pulse was measured.

Table 5: $\quad$ Ultrasonic pulse velocity test results.

\begin{tabular}{|c|c|c|c|c|c|c|}
\hline \multirow{2}{*}{$\begin{array}{c}\text { Date of } \\
\text { casting }\end{array}$} & \multicolumn{3}{|c|}{ Dimensions (mm) } & \multicolumn{3}{c|}{ Test results at 28 days } \\
\cline { 2 - 7 } & Length & Width & Thickness & $\begin{array}{c}\text { Transit } \\
\text { time } \\
(\mu \mathrm{sec})\end{array}$ & $\begin{array}{c}\text { Pulse } \\
\text { velocity } \\
(\mathrm{km} / \mathrm{s})\end{array}$ & $\begin{array}{c}\text { Concrete } \\
\text { quality } \\
\text { grading }\end{array}$ \\
\hline $25 / 01 / 13$ & 150 & 150 & 150 & 34.73 & 4.32 & Excellent \\
\hline
\end{tabular}




\subsubsection{Split tensile test}

Split tensile test on cylinders of size $100 \mathrm{~mm}$ diameter and $200 \mathrm{~mm}$ height was conducted on the compressive testing machine (Aimil, 2000kN) as per specifications given in IS 5816:1999 [12]. The load was applied at a rate of $1.8 \mathrm{kN} / \mathrm{s}$ up to failure of specimen. The average split tensile strength of 3 cylinders was taken after 7 and 28 days.

Table 6: Split tensile strength test results.

\begin{tabular}{|c|c|c|c|c|c|c|}
\hline $\begin{array}{c}\text { Date of } \\
\text { casting }\end{array}$ & \multicolumn{2}{|c|}{ Dimensions (mm) } & \multicolumn{2}{c|}{ Test results at 7 days } & \multicolumn{2}{c|}{ Test results at 28 days } \\
\cline { 2 - 7 } & Length & Diameter & $\begin{array}{c}\text { Failure } \\
\text { load } \\
(\mathrm{kN})\end{array}$ & $\begin{array}{c}\text { Tensile } \\
\text { strength } \\
(\mathrm{MPa})\end{array}$ & $\begin{array}{c}\text { Failure } \\
\text { load } \\
(\mathrm{kN})\end{array}$ & $\begin{array}{c}\text { Tensile } \\
\text { strength } \\
(\mathrm{MPa})\end{array}$ \\
\hline $09 / 02 / 13$ & 200 & 100 & 65.8 & 2.10 & 94.1 & 2.99 \\
\hline
\end{tabular}

\subsubsection{Sulphate and chloride exposure test}

$5 \% \mathrm{Na}_{2} \mathrm{SO}_{4}$ and $5 \% \mathrm{NaCl}$ by volume solutions were prepared and three cubes of size $150 \mathrm{~mm} \times 150 \mathrm{~mm} \times 150 \mathrm{~mm}$ were immersed in each solution after 28 days normal curing for 28 days after taking initial weights. The cubes were weighted and tested on compression testing machine after 28 days.

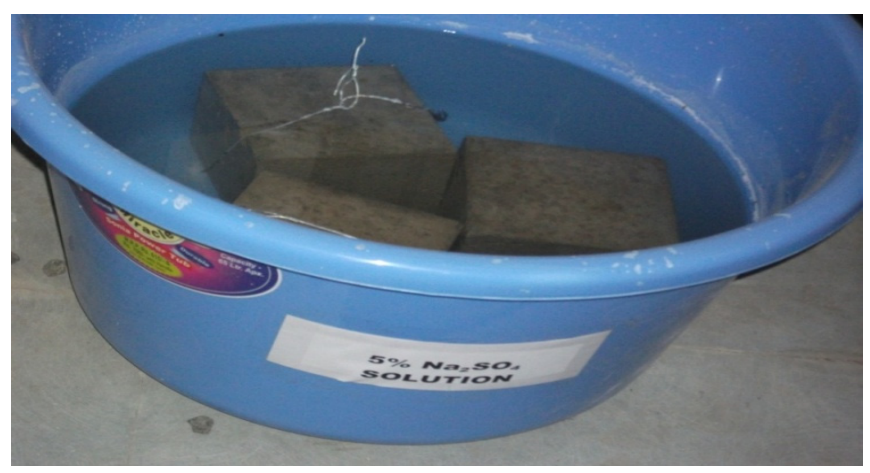

Figure 1: Sulphate exposure of cubes.

Table 7: Immersion in $\mathrm{Na}_{2} \mathrm{SO}_{4}$ solution test results.

\begin{tabular}{|c|c|c|c|c|c|c|c|c|}
\hline \multirow{2}{*}{$\begin{array}{l}\text { Date of } \\
\text { casting }\end{array}$} & \multicolumn{2}{|c|}{ Dimensions (mm) } & \multicolumn{6}{|c|}{ Test results at 28 days } \\
\cline { 4 - 7 } & $\mathrm{L}$ & $\mathrm{W}$ & $\mathrm{T}$ & \multicolumn{2}{|c|}{ Weight (kg) } & $\begin{array}{c}\text { \% loss } \\
\text { in wt. }\end{array}$ & $\begin{array}{c}\text { Failure } \\
\text { load } \\
(\mathrm{kN})\end{array}$ & $\begin{array}{c}\text { Compr. } \\
\text { str. } \\
(\mathrm{MPa})\end{array}$ \\
\cline { 5 - 8 } & & & $\begin{array}{c}\text { Before } \\
\text { immersion }\end{array}$ & $\begin{array}{c}\text { After } \\
\text { immersion }\end{array}$ & & & & \\
\hline $25 / 01 / 13$ & 150 & 150 & 150 & 8.337 & 8.373 & +0.431 & 759.67 & 33.76 \\
\hline
\end{tabular}


Table 8: Immersion in $\mathrm{NaCl}$ solution test results.

\begin{tabular}{|c|c|c|c|c|c|c|c|c|}
\hline \multirow{3}{*}{$\begin{array}{l}\text { Date of } \\
\text { casting }\end{array}$} & \multicolumn{3}{|c|}{ Dimensions (mm) } & \multicolumn{5}{|c|}{ Test results at 28 days } \\
\hline & \multirow[t]{2}{*}{$\mathrm{L}$} & \multirow[t]{2}{*}{$\mathrm{W}$} & \multirow[t]{2}{*}{$\mathrm{T}$} & \multicolumn{2}{|c|}{ Weight (kg) } & \multirow{2}{*}{$\begin{array}{c}\% \% \\
\text { loss in } \\
\text { weight }\end{array}$} & \multirow{2}{*}{$\begin{array}{c}\text { Failure } \\
\text { load }(\mathrm{kN})\end{array}$} & \multirow{2}{*}{$\begin{array}{l}\text { Compr. } \\
\text { Str. } \\
(\mathrm{MPa})\end{array}$} \\
\hline & & & & $\begin{array}{c}\text { Before } \\
\text { immersion }\end{array}$ & $\begin{array}{c}\text { After } \\
\text { immersion }\end{array}$ & & & \\
\hline $25 / 01 / 13$ & 150 & 150 & 150 & 8.327 & 8.363 & +0.432 & 785 & 34.89 \\
\hline
\end{tabular}

\subsubsection{Rapid chloride penetration test}

As per ASTM C1202-12 [13], the amount of electric current passed through $50 \mathrm{~mm}$ thick slices of $100 \mathrm{~mm}$ diameter cylinder was monitored during $6 \mathrm{~h}$ period as shown in Fig. 2. A potential difference of $60 \mathrm{~V}$ DC was maintained across the ends of the specimen, one of which was immersed in a sodium chloride solution, the other in a sodium hydroxide solution. The total charged passed in coulombs was found.

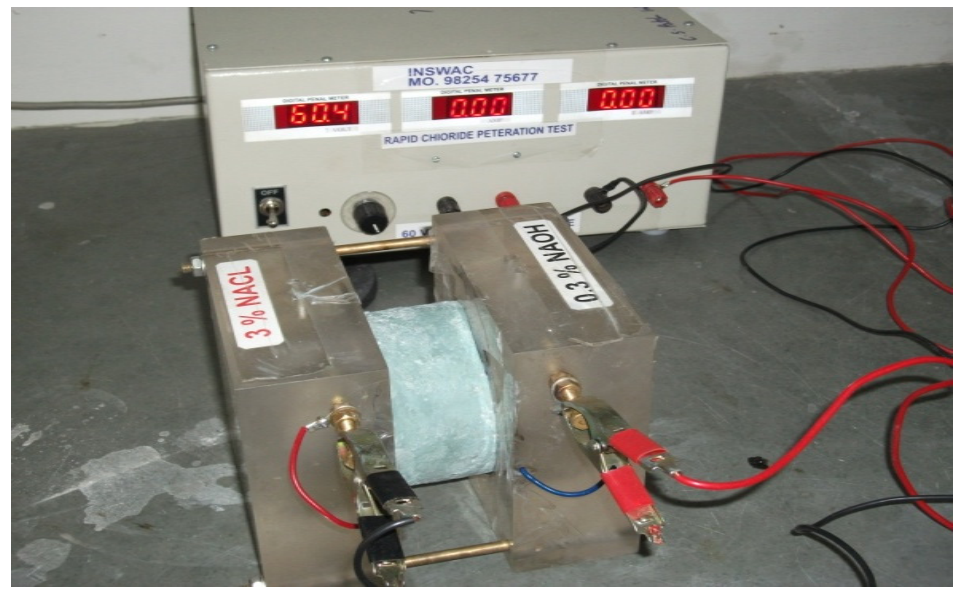

Figure 2: Rapid chloride penetration test.

\section{Results and discussions}

For fresh concrete slump obtained was $32 \mathrm{~mm}$ and compaction factor was 0.848 . From Fig. 3, it can be seen that compressive strength of cubes at 7 days is $22.87 \mathrm{MPa}$ and at 28 days $41.91 \mathrm{MPa}$. The increase in strength is about $83.25 \%$. From the rebound hammer test results as shown in fig. 4, the compressive strength of cube at 7 and 28 days is coming $18.4 \mathrm{MPa}$ and $33.66 \mathrm{MPa}$ corresponding to 18.4 and 31.66 rebound Number. The results of ultrasonic pulse 
velocity shown in Table 5 indicate that quality of concrete was excellent as ultrasonic pulse velocity is $4.32 \mathrm{~km} / \mathrm{s}$. Fig. 4 shows that the split tensile strength of cylinders at 7 and 28 days are $2.10 \mathrm{MPa}$ and $2.99 \mathrm{MPa}$ respectively. The increase in strength is about $42.38 \%$. Table 7 indicates that there is an increase in weight of cubes when immersed in $\mathrm{Na}_{2} \mathrm{SO}_{4}$ solution for 28 days by $0.368 \mathrm{~kg}$ and compressive strength is $33.76 \mathrm{MPa}$. Therefore there is an increase in weight by $0.431 \%$ and decrease in strength by $19.45 \%$. Table 8 indicates that there is an increase in weight of cubes when immersed in $\mathrm{NaCl}$ solution for 28 days by $0.360 \mathrm{~kg}$ and compressive strength is $34.89 \mathrm{MPa}$. Therefore there is an increase in weight by $0.432 \%$ and decrease in strength by $18.75 \%$. Table 9 indicates that there is increase in chloride ion permeability by $11 \%$ at 56 days.

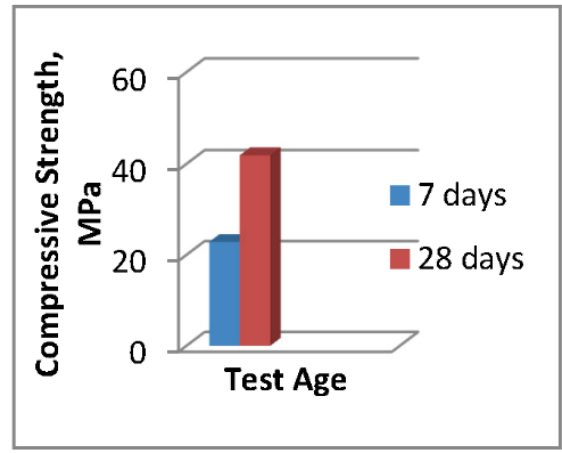

Figure 3: Compressive strength of cubes.

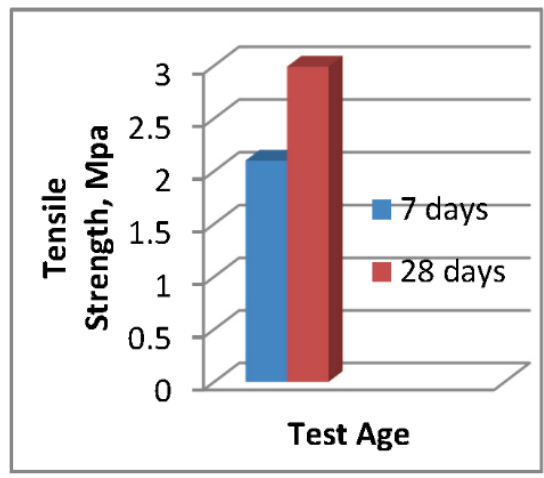

Figure 5: Split tensile strength of cylinders.

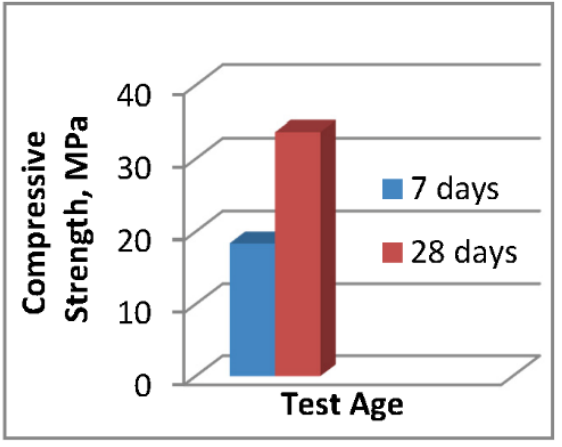

Figure 4: Compressive strength from rebound number.

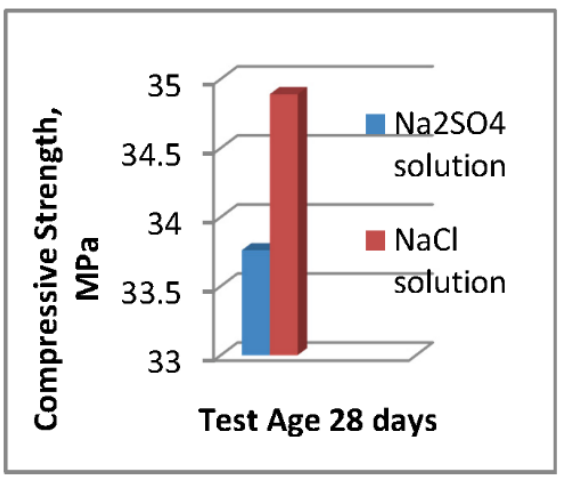

Figure 6: Compressive strength of cubes after immersion in solution. 
Table 9: Rapid chloride penetration test results.

\begin{tabular}{|c|c|c|c|c|c|c|}
\hline \multirow{2}{*}{$\begin{array}{c}\text { Date of } \\
\text { casting }\end{array}$} & \multicolumn{2}{|c|}{$\begin{array}{c}\text { Dimensions } \\
(\mathrm{mm})\end{array}$} & \multicolumn{2}{c|}{ Test results at 28 days } & \multicolumn{2}{c|}{ Test results at 56 days } \\
\cline { 2 - 7 } & $\mathrm{L}$ & $\mathrm{D}$ & $\begin{array}{c}\text { Charge passed } \\
(\text { coulomb })\end{array}$ & $\begin{array}{l}\text { Chloride ion } \\
\text { permeability }\end{array}$ & $\begin{array}{c}\text { Charge passed } \\
\text { (coulomb) }\end{array}$ & $\begin{array}{c}\text { Chloride ion } \\
\text { permeability }\end{array}$ \\
\hline $09 / 02 / 13$ & 50 & 100 & 2241 & Moderate & 2520 & Moderate \\
\hline
\end{tabular}

\section{Conclusions}

The following are the conclusions from the present study.

- Normal strength concrete is excellent as far as normal exposure is considered as it has shown very good compressive strength at 7 and 28 days. 7 days' strength was more than $2 / 3$ of 28 days strength.

- Non destructive tests also confirmed good quality of concrete as pulse velocity and rebound hammer number were $4.32 \mathrm{~km} / \mathrm{s}$ and 31.66 respectively.

- Split tensile strength was around 1/10 of expected compressive strength at 7 and 28 days which indicate good casting quality.

- The normal strength concrete casted shows marginal increase in weight when exposed to $\mathrm{Na}_{2} \mathrm{SO}_{4}$ and $\mathrm{NaCl}$ solution for 28 days but Compressive Strength reduces drastically by $19.45 \%$ and $18.75 \%$ respectively.

- $\mathrm{Na}_{2} \mathrm{SO}_{4}$ decompose the C-S-H and produce ettringite which has no binding properties and therefore reduce the strength. The failure mode of $\mathrm{Na}_{2} \mathrm{SO}_{4}$ exposed concrete is different than conventional concrete. In $\mathrm{Na}_{2} \mathrm{SO}_{4}$ exposed cubes, cracks propagate rapidly through the cubes on increasing load and get crushed. $\mathrm{NaCl}$ exposed concrete fails almost in similar way as conventional concrete.

- Chloride ion permeability increased by $11 \%$ after 56 days shows that at higher ages normal strength concrete remains porous even if hydration is completed.

- From the research it was proposed that, to improve mechanical and durability related properties of normal strength concrete, mineral and chemical admixtures have to be utilized in making concrete.

\section{Acknowledgement}

The authors wish to acknowledge C S Patel Institute of Engineering and Technology, Charotar University of Science and Technology, Changa, Gujarat, India for providing all the facilities for carrying out this work. 


\section{References}

[1] Fan Y.F., Chen Y.S., Hu Z.Q. and Li X., "Experimental Study on Compressive Strength of Corroded Concrete", $31^{\text {st }}$ Conference on Our World in Concrete \& Structures, 2006.

[2] Murli G, Sudhhapriya G, Sijiraju, Mahalakshmi C, Srinidhi G and Zachariah D S, "An Experimental Investigation of Various Industrial Effluents on Concrete", International Journal of Engineering Research and Applications, Vol. 2, Issue 2, 2012, pp. 247-250.

[3] Shahul Hameed M, Saraswathi V and Sekar A S S, "Rapid Chloride Permeability Test on Self Compacting High Performance Green Concrete", ndt.net, 2010.

[4] Sengupta A K, Menon D, "Prestressed Concrete Structures", nptel.iitm.ac.in.

[5] Reddy M, Ramma Reddy I V, Madan Mohan Reddy K, Basheerudeen A and Krishnamurthi N, "Durability Characteristics of High Strength Concrete", International Journal of Emerging Trends in Engineering and Development, Vol. 7, Issue 2, 2012, pp. 331-338.

[6] Brindha D, Baskaran T and Nagan S, "Assessment of Corrosion and Durability Characteristics of Copper Slag Admixed Concrete", International Journal of Civil and Structural Engineering, Vol. 1, No. 2, 2010, pp. 192-211.

[7] IS 12269: 1987, Specification for 53 grade ordinary Portland cement, Bureau of Indian Standards, New Delhi.

[8] IS 383: 1970, Specification for coarse and fine aggregate from natural sources for concrete, Bureau of Indian Standards, New Delhi.

[9] IS 516: 1959, Methods of Tests for Strength of concrete, Bureau of Indian Standards, New Delhi.

[10] IS 13311 (part 2): 1992, Non Destructive Testing of Concrete-Methods of Test, Part 2 Rebound Hammer, Bureau of Indian Standards, New Delhi.

[11] IS 13311 (part 1): 1992, Non Destructive Testing of Concrete-Methods of Test, Part 1 Ultrasonic Pulse Velocity, Bureau of Indian Standards, New Delhi.

[12] IS 5816:1999, splitting tensile strength of concrete-method of test, Bureau of Indian Standards, New Delhi.

[13] ASTM C1202-12, Standard Test Method for Electrical Indication of Concrete's Ability to Resist Ion Penetration.

[14] Shetty M S, Concrete Technology - Theory and Practice, 2005 edition, S Chand and Co. Ltd., New Delhi. 